УДК 342.95

DOI: https://doi.org/10.54929/pmtl-issue2-2021-10

\title{
ПРАВОВІ ЗАСАДИ ВИКОРИСТАННЯ ЕЛЕКТРОННИХ ІНФОРМАЦІЙНИХ РЕСУРСІВ В КОНЦЕПЦІЇ ЦИФРОВОЇ ДЕРЖАВИ
}

\author{
LEGAL PRINCIPLES OF USING ELECTRONIC INFORMATION \\ RESOURCES IN THE CONCEPT OF THE DIGITAL STATE
}

\author{
Блінова Г. О. \\ доктор юридичних наук, доцент, \\ профресор кафедри цивільного, господарського та екологічного права \\ Національний технічний університет «Дніпровська політехніка» \\ ORCID: 0000-0002-3320-585X \\ Hanna Blinova \\ Doctor of Law, Associate Professor, \\ Professor of the Department of Civil, Economic and Environmental Law \\ National Technical University «Dnipro Polytechnic»
}

Досліджено зміст поняття «цифрова держава». Визначено індикатори становлення в Україні системи суспільних відносин, характерних для цифрової держави. Висвітлено основні напрями фрормування державної політики обумовлені реалізацією потреб інформаційного суспільства, цифрового виробництва та електронного урядування в Україні. Визначено сучасний стан правового регулювання процесів формування цифрової інфраструктури України та перспективи його удосконалення відповідно до міжнародних норм. Доведено, що основне призначення державних електронних інформаційних ресурсів - це задоволення інформаційних потреб органів публічної адміністрації. Визначено загальні засади правового регулювання фрормування, експлуатації, модернізації, ліквідації державних електронних інформаційних ресурсів. 3'ясовано основне коло державних електронних інформаційних ресурсів та органів публічної адміністрації, що є їх держателями та користувачами. Метою статmі є аналіз специфіки правового регулювання суспільних відносин у сфрері використання електронних інформаційних ресурсів в аспекті становлення цифрової держави в Україні. Реалізація поставленої мети передбачає вирішення низки завдань: 1) розкриття сутності поняття «цифрова держава»; 2) ілюстрація їі проявів в Україні; 3) дослідження державних електронних інформаційних ресурсів як об'єкту суспільних відносин. Наукова новизна. У статті розглянуто такі елементи цифрової держави в Україні як: електронне урядування, електронне правосуддя, електронна система охорони здоров'я, електронна торгівля, цифрові робочі місця, державні електронні інформаційні ресурси та інше. Як висновок, у статті наголошується, що виявлено відсутність повноцінної електронної взаємодії між державними інфрормаційними ресурсами та пов'язані із нею проблеми електронного урядування; проблеми правового регулювання функціонування та використання органами публічної адміністрації державних електронних інформаційних ресурсів; доведено термінологічна не узгодженість різних нормативно-правових актів, що визначають порядок функціонування та використання державних електронних інформаційних ресурсів. Обгрунтовано необхідність розробки та нормативного закріплення загальних засад та принципів організації, функціонування, використання, зберігання державних електронних інформаційних ресурсів. Ключові слова: цифрова держава, електронні ресурси, інформація, органи публічної адміністрації, електронне урядування.

Исследовано содержание понятия «цифровое государство». Определены индикаторы становления в Украине системы общественных отношений, характерных для цифрового государства. Освещены основные направления формирования государственной политики, обусловленные реализацией потребностей информационного общества, цифрового производства и электронного управления в Украине. Определено современное состояние правового регулирования процессов формирования цифровой инфраструктуры Украины и перспективы его усовершенствования в соответствии с международными нормами. Доказано, что основное назначение государственных электронных информационных ресурсов - удовлетворение информационных потребностей органов публичной администрации. Определены общие принципы правового регулирования фрормирования, эксплуатации, модернизации, ликвидации государственных электронных информационных ресурсов. Выяснен основной круг государственных электронных информационных ресурсов и органов публичной администрации, являющихся их держателями и пользователями. Цель статьи - анализ специфики правового регулирования общественных отношений в сфере использования электронных информационных ресурсов в аспекте становления цифрового государства в Украине. Реализация поставленных целей предполагает решение ряда задач: 1) раскрытие сущности понятия «цифрровое государство»; 2) иллюстрация ее проявлений в Украине; 3) исследование государственных электронных информационных ресурсов как объекта публичных отношений. Научная новизна. В статье рассмотрены 
такие элементы цифрового государства в Украине как: электронное управление, электронное правосудие, электронная система здравоохранения, электронная торговля, цифровые рабочие места, государственные электронные информационные ресурсы. Как вывод, в статье отмечается, что выявлено отсутствие полноценного электронного взаимодействия между государственными информационными ресурсами и связанные с ним проблемы электронного управления; проблемы правового регулирования фрункционирования и использования публичной администрации государственных электронных информационных ресурсов; доказана терминологическая не согласованность различных нормативно правовых актов, определяющих порядок функционирования и использования государственных электронных информационных ресурсов. Обоснована необходимость разработки и нормативного закрепления общих принципов и принципов организации, функционирования, использования, хранения государственных электронных информационных ресурсов. Ключевые слова: цифровое государство, электронные ресурсы, информация, органы публичной администрации, электронное управление.

The meaning of the concept of "digital state" is investigated. Indicators of formation of the system of public relations characteristic of the digital state in Ukraine are determined. The main directions of state policy formation due to the implementation of the needs of the information society, digital production and e-government in Ukraine are highlighted. The current state of legal regulation of the processes of formation of digital infrastructure of Ukraine and prospects for its improvement in accordance with international norms are determined. It is proved that the main purpose of state electronic information resources is to meet the information needs of public administration bodies. The general principles of legal regulation of formation, operation, modernization, liquidation of state electronic information resources are determined. The main range of state electronic information resources and public administration bodies that are their holders and users has been clarified. The aim of the article is to analyze the specifics of legal regulation of public relations in the field of electronic information resources in terms of the formation of the digital state in Ukraine. Realization of the set purpose provides the decision of a number of tasks: 1) disclosure of essence of concept "digital state"; 2) illustration of its manifestations in Ukraine; 3) research of state electronic information resources as an object of public relations. Scientific novelty. The article considers such elements of the digital state in Ukraine as: e-government, e-justice, e-health system, e-commerce, digital jobs, state e-information resources and more. In conclusion, the article emphasizes that the lack of full-fledged electronic interaction between state information resources and related problems of e-government; problems of legal regulation of functioning and use of state electronic information resources by public administration bodies; the terminological inconsistency of various normative legal acts that determine the order of functioning and use of state electronic information resources has been proved. The necessity of development and normative consolidation of general principles and principles of organization, functioning, use, storage of state electronic information resources is substantiated. Key words: digital state, electronic resources, information, public administration bodies, e-government.

Постановка проблеми. Відсутність системної е-взаємодії в Україні призводить до того, що громадяни витрачають багато часу та ресурсів на одержання різних довідок та документів для подальшого отримання комплексних адміністративних послуг (наприклад ліцензій, дозволів), а органи влади продовжують взаємодіяти «паперами», або змушені через відсутність електронної взаємодії дублювати (тобто вести власні) реєстри та системи. Ключовим рішенням є запровадження електронної взаємодії та інтероперабельності «цифрових» систем державних установ шляхом використання єдиних відкритих стандартів, вимог та форматів, у т.ч. запровадження системи електронної взаємодії та підключення до неї не менше 50 державних реєстрів, наповнення єдиного демографрічного реєстру та зв'язування даних в різних реєстрах за допомогою ID громадянина, запровадження 100\%- го обміну документами в електронній фрормі (Цифрова адженда України, 2020).

Реалізація зазначених заходів дозволить створити ефективну систему електронного урядування. Стратегія реформування державного управління України на 2016-2020 роки визначає електронне урядуванням як використання інформаційно-комунікаційних технологій для покращення ефективності системи державного управління, її прозорості та зручності, зокрема операційного компонента, що забезпечує діяльність державних органів. Основним завданням у цій сорері є створення (удосконалення) реєстрів даних громадян, юридичних осіб, земельних ділянок і нерухомості, податків, соціального страхування, забезпечення функціональної сумісності систем та здійснення обміну даними на операційному рівні замість подання довідок та інших документів. Електроннне урядування передбачає функціональну сумісність систем, що сприятиме здійсненню обміну даними між реєстрами та установами, відкритість реєстрів для користування органами державного управління із забезпеченням гарантованого захисту персональних даних, що сприятиме спрощенню процедури надання органами державного управління адміністративних послуг громадянам і юридичним особам з підтвердження фактів та інформації, що міститься в офіційних державних реєстрах, зокрема в електронній фрормі через веб-сервіси (Стратегія реформування державного управління України на 2016-2020 роки, 2016).

Забезпечення електронної взаємодії державних інформаційних ресурсів та розвиток інфраструктури інтероперабельності $€$ головним викликом для розвитку електронного урядування в Україні, 
зазначено у Концепції розвитку цифрової економіки та суспільства України на 2018-2020 роки. Практично кожний державний орган стикається з необхідністю доступу до того чи іншого державного реєстру або бази даних. Електронні закупівлі, система електронних декларацій, єдине митне вікно тощо для свого повноцінного функціонування потребують інтеграції з багатьма державними реєстрами та базами даних. Відсутність електронної взаємодії державних систем не дає змоги спростити порядок надання послуг та виконати вимоги Закону України «Про адміністративні послуги» щодо заборони вимагати від суб'єктів звернення інфрормацію або дані, що перебувають в інших органах влади, тобто вже були надані громадянами раніше (Про схвалення Концепції розвитку цифрової економіки та суспільства України на 2018-2020 роки та затвердження плану заходів щодо ії реалізації, 2018).

Якісна, логічно побудована на єдиних засадах, з урахуванням європейських та міжнародних принципів, система інформаційного забезпечення органів публічної адміністрації, що включає усі державні електронні інформаційні ресурси, є основою цифрової держави в Україні.

Аналіз останніх досліджень і публікацій. Аналіз наукової літератури свідчить про те, що існує чимало досліджень, спрямованих на вирішення проблеми цифровізації публічного управління та цифрової держави зокрема.

Формулювання цілей статті (постановка завдання). Метою статті $є$ аналіз специфріки правового регулювання суспільних відносин у сфері використання електронних інформаційних ресурсів в аспекті становлення цифрової держави в Україні. Реалізація поставленої мети передбачає вирішення низки завдань: 1) розкриття сутності поняття «цифрова держава»; 2) ілюстрація іiї проявів в Україні; 3) дослідження державних електронних інформаційних ресурсів як об'єкту суспільних відносин.

Виклад основного матеріалу дослідження. Майбутнє України - цифррова держава. Соціальні, політичні, економічні та правові індикатори свідчать про прискорення перебудови усіх державних структур у цьому напрямку, що обумовлено вимогами сучасного інформаційного суспільства. Порядком денним асоціації Україна - ЄС ще у 2009 році було визначено, що сторони співпрацюють щодо підготовки до імплементації актів acquis $€ С$ шляхом обміну інформацією та досвідом реалізації ініціативи ЄC «і2010» з метою розробки та впровадження е-стратегій в Україні, включаючи впровадження Національної концепції розвитку телекомунікацій та державної програми «е-Україна» (Порядок денний асоціації Україна - $Є С$ для підготовки та сприяння імплементації Угоди про асоціацію, 2009). Додаток XVII-3 до Розділу IV Угоди про асоціацію вже зобов'язував Україну здійснити імплементацію низки актів ЄС, що встановлюють спільні норми на ринку надання електронних комунікаційних послуг. Також Угода передбачає, що у цій всеосяжній сфрері має бути прийнята дорожня карта змін (Черніков, 2019). Серед окреслених Угодою про асоціацію актів Європейського Союзу у цій сфрері засадничим $є$ Рамкова Директива $€ C / 2002 / 21$ про спільні правові рамки у ссрері електронних комунікаційних мереж та послуг, а також низка директив і регламентів (Черніков, 2019). Наукова спільнота, представники бізнесу, громадські діячі та суб'єкти владних повноважень активно ініціюють процеси формування елементів цифрової держави в Україні.

Показником руху України до стандартів цифррової держави $€$ також прийняття та оновлення таких Законів як «Про інфрормацію», «Про захист персональних даних», «Про доступ до публічної інфрормації», «Про електронні документи та електронний документообіг», «Про електронні довірчі послуги», «Про телекомунікації» тощо.

Розпорядження Кабінету Міністрів України від 20.09.2017 № 649-р. «Про схвалення Концепції розвитку електронного урядування в Україні», від 8 листопада 2017 р. № 797-р «Про схвалення Концепції розвитку електронної демократії в Україні та плану заходів щодо ії реалізації» та від 17 січня 2018 р. № 67-р «Про схвалення Концепції розвитку цифрової економіки та суспільства України на 2018-2020 роки та затвердження плану заходів щодо ії̈ реалізації» створюють передумови для виникнення нових цілей, інтересів та потреб в інфрормаційній сфрері органів публічної адміністрації а саме запровадження: інформаційно-телекомунікаційних систем підтримки прийняття управлінських рішень та автоматизації адміністративних процесів; цифрової демократії, а саме інфрормаційного забезпечення е-парламенту, е-голосування, е-правосуддя, е-медіації, е-референдумів, е-консультацій, е-петицій, е-політичних кампаній, е-опитування; реалізації концепції смарт-сіті - «Розумне місто»; цифрових державних платформ; концепції блокчейну; забезпечення електронної взаємодії державних інформаційних ресурсів та розвитку інфрраструктури інтероперабельності; запровадження цифровізації державних установ, багатоканального інформування та залучення громадян, концепції відкритих даних з використанням електронних платфрорм, наприклад «Громадянське суспільство і влада», чи «Єдина система місцевих петицій»; тощо (Про схвалення Концепції розвитку електронного урядування в Україні, 2017; Про схвалення Концепції розвитку електронної демократії в Україні та плану заходів щодо її реалізації, 2017; Про схвалення Концепції розвитку цифрової економіки та суспільства України на 2018-2020 роки та затвердження 
плану заходів щодо її реалізації, 2018). Зазначене $€$ елементами електронної держави.

Україна визначила цифрову трансформацію як пріоритетну політику, що вже відзначено нещодавніми успіхами у впровадженні систем ProZorro та eHealth, у запровадженні мобільного покриття 4G та запуску електронних послуг у державному та приватному секторах. Цифровізація України проводиться спільними зусиллями з боку експертних та ділових спільнот. До пріоритетів Цифрового порядку денного України належать законодавство про цифрову економіку та телекомунікації, цифрову інфраструктуру, а саме стратегію з розвитку високошвидкісного широкосмугового доступу до інтернету, Програма безготівкової економіки у сфрерах електронної торгівлі еTrade, електронного захисту eTrust та кібербезпеки Cybersecurity, ініціатива «Розумні міста - розумні регіони», яка зосереджена на децентралізації та реалізації програми електронних навичок eSkills, електронної системи охорони здоров'я eHealth та електронної торгівлі еTrade в регіонах України (ЄС запускає в Україні нову програму EU4Digital для покращення онлайн-сервісів, 2019).

22 травня 2019 року Європейський Союз офіційно запустив в Україні нову програму«EU4Digital: підтримка цифрової економіки та суспільства у Східному партнерстві». EU4Digital націлена на розширення переваг Єдиного цифрового ринку Європейського Союзу для України та інших держав Східного партнерства з метою стимулювання економічного росту, створення робочих місць, покращення життя людей та допомоги бізнесу (ЄС запускає в Україні нову програму EU4Digital для покращення онлайн-сервісів, 2019).

В умовах становлення в Україні цифрової держави, на наш погляд, стає «цифрове» робоче місце державного службовця. Саме тому особливу роль у зазначених вище документах відведено перетворенню робочих місць державних службовців на цифрові робочі місця, оскільки державне управління України в умовах зростання кількості завдань, ініціатив, проектів та одночасної оптимізації витрат має базуватися саме на технологічних і цифрових формах забезпечення його безперебійного функціонування. «Цифрове робоче місце» сприятиме гнучкості в методах виконання посадових обов'язків державними службовцями, стимулюватиме їхню спільну роботу та взаємодію, підтримуватиме децентралізовані та мобільні робочі середовища й передбачає вибір державним службовцем технологій для роботи для забезпечення кінцевої мети сервісної держави - надання її громадянам якісних і доступних адміністративних послуг (Уряд хоче запровадити для держслужбовців віртуальні робочі місця. 2019).

«Цифрове» робоче місце - це віртуальний еквівалент фрізичного робочого місця, котрий вимагає належної організації, користування та управління, оскільки воно має стати запорукою підвищеної ефективності працівників та створення для них більш сприятливих умов праці (Лопушинський, 2018). Запорукою успішності реалізації концепції цифрових робочих місць державних службовців $\epsilon$ ефрективна взаємодія державних електронних ресурсів.

Постановою Кабінету Міністрів України «Про деякі питання електронної взаємодії державних електронних інформаційних ресурсів» передбачено запровадження системи електронної взаємодії державних електронних інформаційних ресурсів відповідно до вимог ЄС (Деякі питання організації електронної взаємодії державних електронних інформаційних ресурсів, 2018).

Положення про електронну взаємодію державних електронних інформаційних ресурсів визначає загальні засади здійснення обміну електронними даними, крім інформації, що становить державну таємницю, між суб'єктами владних повноважень з державних електронних інформаційних ресурсів під час надання адміністративних послуг та здійснення інших повноважень відповідно до покладених на них завдань. Система електронної взаємодії державних електронних інформаційних ресурсів призначена для автоматизації та технологічного забезпечення обміну електронними даними між суб'єктами владних повноважень з державних електронних інформаційних ресурсів під час надання адміністративних послуг та здійснення інших повноважень відповідно до покладених на них завдань шляхом використання сервіс-орієнтованої архітектури, що є інтерфейсами прикладного програмування доступу до державних електронних інформаційних ресурсів, побудованими згідно з єдиними вимогами, а також шляхом використання єдиних форматів, протоколів, довідників, шаблонів та класифікаторів (Положення про електронну взаємодію державних електронних інформаційних ресурсів, 2016).

Порядок організації електронної інформаційної взаємодії державних електронних інформаційних ресурсів визначає механізм організації електронної інформаційної взаємодії державних електронних інформаційних ресурсів. Для організації електронної інформаційної взаємодії державних електронних інформаційних ресурсів суб'єкти владних повноважень використовують засоби програмного комплексу Національного реєстру електронних інформаційних ресурсів. Державне агентство з питань електронного урядування створює за допомогою засобів програмного комплексу Національного реєстру особисті кабінети суб'єктів владних повноважень із розміщеними в них формами заявок постачальника і отримувача (Порядок організації електронної інфрормаційної взаємодії державних електронних інформаційних ресурсів, 
2018).

Національний реєстр електронних інформаційних ресурсів ведеться з метою запровадження єдиної системи обліку електронних інформаційних ресурсів держави і формується з використанням новітніх досягнень у сфрері інфрормаційнотелекомунікаційних технологій. Національний реєстр електронних інфрормаційних ресурсів це інформаційно-телекомунікаційна система, призначена для реєстрації, обліку, накопичення, оброблення і зберігання відомостей про склад, зміст, розміщення, умови доступу до електронних інформаційних ресурсів та задоволення потреб юридичних і фрізичних осіб в інформаційних послугах. До Національного реєстру включається інфрормація про державні електронні реєстри, кадастри, державні та інші обов'язкові класифрікатори, а також інформаційні системи, які забезпечують їх функціонування та використовують інформацію з них. Замовником і утримувачем Національного реєстру $є$ Державне агентство з питань електронного урядування. Створення, фрунціонування та вдосконалення ведення Національного реєстру забезпечується за рахунок бюджетних коштів, передбачених на цю мету Державному агентству з питань електронного урядування. Органи державної влади, органи місцевого самоврядування та інші юридичні особи публічного права користуються інформаційним фондом Національного реєстру безоплатно (Положення про Національний реєстр електронних інформаційних ресурсів, 2004).

Положення про електронну взаємодію державних електронних інформаційних ресурсів передбачено перелік пріоритетних державних електронних інформаційних ресурсів, що підлягають реєстрації Національному реєстрі електронних інфоормаційних ресурсів: Єдиний державний реєстр юридичних осіб, фрізичних осіб - підприємців та громадських формувань, Державний реєстр речових прав на нерухоме майно, Державний реєстр актів цивільного стану громадян, Єдиний реєстр довіреностей, Державний реєстр обтяжень рухомого майна, Державний земельний кадастр, Єдиний державний демографічний реєстр, Державний реєстр фізичних осіб - платників податків, Реєстр платників податку на додану вартість, Єдиний державний автоматизований реєстр осіб, які мають право на пільги, Єдина інформаційна система Міністерства внутрішніх справ, Єдиний державний реєстр Міністерства внутрішніх справ стосовно зареєстрованих транспортних засобів та їх власників, Державний реєстр загальнообов'язкового державного соціального страхування, Державний реєстр виборців, Єдиний державний реєстр судових рішень, Єдиний реєстр документів, що дають право на виконання підготовчих та будівельних робіт і засвідчують прийняття в експлуатацію за- кінчених будівництвом об'єктів, відомостей про повернення на доопрацювання, відмову у видачі, скасування та анулювання зазначених документів, Єдиний реєстр об'єктів державної власності, Електронна система охорони здоров'я, Єдина державна електронна база з питань освіти (Положення про електронну взаємодію державних електронних інформаційних ресурсів, 2016).

Створення та функціонування зазначених державних електронних інформаційних ресурсів регулюється такими групами нормативно-правових актів як: 1) Кодекси України; 2) Закони України; 3) Постанови Кабінету Міністрів України; 4) Накази Міністерства юстиції України; 5) нормативноправові акти інших міністерств та відомств та інші.

Наведений вище перелік державних електронних інформаційних ресурсів не $є$ вичерпним. Вітчизняне законодавство України передбачає функціонування та використання ще таких реєстрів як: Єдиний реєстр спеціальних бланків нотаріальних документів, Єдиний реєстр нотаріусів, Реєстр спеціальних бланків документів інформаційної системи Міністерства юстиції України, Спадковий реєстр, Єдиний державний реєстр осіб, які вчинили корупційні правопорушення, Єдиний державний реєстр осіб, щодо яких застосовано положення Закону України «Про очищення влади», Єдиний реєстр підприємств, щодо яких порушено провадження у справі про банкрутство, Єдиний реєстр арбітражних керуючих, Реєстр методик проведення судових експертиз, Державний реєстр атестованих судових експертів, Єдиний державний реєстр нормативно-правових актів, Електронний реєстр апостилів, Єдиний реєстр заборон відчуження об'єктів нерухомого майна; Реєстр прав власності на нерухоме майно, Державний реєстр іпотек, Реєстр неприбуткових установ та організацій, Державний реєстр друкованих 3МІ та інформаційних агентств як суб'єктів інфрормаційної діяльності, Єдиного державного реєстру про державну реєстрацію створення юридичної особи та її відокремленого підрозділу, відокремленого підрозділу іноземної неурядової організації, представництва, фрілії іноземної благодійної організації та інші реєстри. Усі реєстри створені для накопичення, систематизації та полегшення використання відповідної інформації для задоволення інформаційних потреб органів публічної адміністрації, суспільства та громадян.

Висновки та перспективи подальших досліджень. Аналіз вітчизняних нормативно-правових акті, що регулюють порядок використання органами публічної адміністрації державних електронних інфрормаційних ресурсів, виявив значні проблеми правового регулювання їх функціонування та використання органами публічної адміністрації.

Першою проблемою $є$ термінологічна не узгодженість різних нормативно-правових 
актів, що визначають порядок функціонування та використання державних електронних інформаційних ресурсів. Національне законодавство використовує для формулювання понять різних державних електронних інформаційних ресурсів такі терміни як: «автоматизована інформаційнотелекомунікаційна система», «державний реєстр», «єдиний державний реєстр», «веб-портал», «автоматизована система збирання, зберігання, захисту, обліку, пошуку та надання», «портал електронних сервісів», «база даних», «геоінформаційна система», «інформаційна (автоматизована) система», «електронна інформаційно-телекомунікаційна система», «багатофункціональна інтегрована автоматизована система», «програмно-інформаційний комплекс», «організаційно-технічна система» та інші. Це свідчить про відсутність єдиних методологічних засад визначення змісту, структури, критеріїв систематизації державних електронних інформаційних ресурсів.

По-друге, відсутня будь-яка систематизація чи класифікація державних електронних інформаційних ресурсів, закріплена на рівні нормативноправового акту. 3 урахуванням проведеного аналізу, на наш погляд, при формування такої класифрікації можна використовувати такі критерії групування цих державних електронних інформаційних ресурсів як: 1) сфера їх використання; 2) держатель реєстру; 3) адміністратор реєстру; 4 ) основне коло користувачів реєстру; 4) термін дії реєстру; 5) режим доступу до інформації, що у реєстрі зберігається; 6) право власності на реєстр; 7) територія на якій використовується реєстр; 8) обсяг інформації в реєстрі; 9) ступень систематизації інформації; 10) спосіб та порядок доступу до інформації з реєстру; 11) платність доступу до реєстру; 12) рівень нормативно-правового акту, що визначає правила його функціонування; 13) мета створення реєстру (призначення реєстру); 14) складність структури реєстру; 15) кількість органів публічної адміністрації, інформаційні потреби яких задовольняє реєстр та інше. Віднесення державних електронних інформаційних ресурсів до тієї чи іншої групи повинно мати наслідком застосування окремо визначених принципів їх функціонування.

Третьою проблемою є відсутність загальних засад та принципів організації, функціонування, використання, зберігання державних електронних інфрормаційних ресурсів. Одні нормативно-правові акти, яких меншість, містять певні засади, інші ні. Проте, навіть зазначені засади та принципи організації, функціонування, використання, зберігання державних електронних інформаційних ресурсів разюче відрізняються одне від одного. На наш погляд, потребує подальших наукових досліджень аналіз принципів функціонування державних електронних інформаційних ресурсів. При цьому, ми вважаємо, такі засади слід групувати за певними етапами, наприклад: принципи створення державних електронних інформаційних ресурсів, принципи зберігання інформації в державних електронних інформаційних ресурcax, принципи оновлення, передання, перевірки, архівування, надання, обміну інформацією з ресурсів тощо. Це дозволить сформувати струнку систему державних електронних інформаційних ресурсів, що функціонуватиме на одних і тих же основних засадах, що у свою чергу, підвищить рівень інтегрованості та сумісності державних електронних інформаційних ресурсів. В основу формування системи принципів фрнкціонування державних електронних інформаційних ресурсів повинні бути закладені загальноєвропейські та міжнародні засади організації інфраструктури цифрової держави.

У зв'язку із зазначеним, вважаємо за потрібне розробити та прийняти Закони України «Про державні електронні інформаційні ресурси». У цьому нормативно-правовому акті пропонуємо закріпити принципи створення, фрункціонування, збереження, використання, забезпечення безпеки доступу до державних електронних інформаційних ресурсів тощо; сформулювати загальні засади управління зазначеними процесами; унормувати та конкретизувати поняття, що використовуються у цій сорері; систематизувати суб'єктів суспільних відносин, що виникають у зв'язку із використанням державних електронних інформаційних ресурсів, визначити їх правовий статус (гарантії діяльності, задачі, функції, права та обов'язки, відповідальність) та порядок їх взаємодії; конкретизувати відповідальність за порушення цього законодавства; визначити порядок здійснення контролю та нагляду за функціонуванням таких ресурсів; зафіксувати напрями удосконалення технічного забезпечення функціонування цих ресурсів з урахуванням відповідних міжнародних стандартів.

\section{БІБЛІОГРАФІЧНИЙ СПИСОК:}

1. Цифрова адженда України - 2020 («Цифровий порядок денний» - 2020): Концептуальні засади (версія 1.0). Першочергові сфери, ініціативи, проекти «цифровізації» України до 2020 року: Проект. URL: https://ucci. org.ua/uploads/files/58e78ee3c3922.pdf.

2. Стратегія реформування державного управління України на 2016-2020 роки : Розпорядження Кабінету Міністрів України від 24 червня 2016 р. № 474-р. Урядовий кур’єр от 27.07.2016 — № 139.

3. Про схвалення Концепції розвитку цифрової економіки та суспільства України на 2018-2020 роки та затвердження плану заходів щодо її реалізації: Розпорядження Кабінету Міністрів України від 17 січня 2018 р. № 
67-р. Урядовий кур’єр від 11.05.2018. № 88.

4. Порядок денний асоціації Україна - ЄС для підготовки та сприяння імплементації Угоди про асоціацію. «Україна - Європейський Союз: зібрання міжнародних договорів та інших документів (1991-2009). 2009. URL: https://zakon.rada.gov.ua/laws/show/994_990/print.

5. Черніков Д. Нині в Європі успішно реалізується стратегія Єдиного цифрового ринку - Digital Single Market Strategy. 2019. URL: https://www.ukrinform.ua/rubric-economy/2364078-misia-ocifruvati-ekonomiku-strategiaedinogo-cifrovogo-rinku.html.

6. Про схвалення Концепції розвитку електронного урядування в Україні: Розпорядження Кабінета Міністрів України від 20.09.2017 № 649-р : Урядовий кур’єр від 27.09.2017 — № 181.

7. Про схвалення Концепції розвитку електронної демократії в Україні та плану заходів щодо її реалізації: Розпорядження Кабінета Міністрів України від 8 листопада 2017 р. № 797-р. Урядовий кур’єр від 17.11.2017 - № 217.

8. Про схвалення Концепції розвитку цифрової економіки та суспільства України на 2018-2020 роки та затвердження плану заходів щодо ії реалізації: Розпорядження Кабінету Міністрів України від 17 січня 2018 р. № 67-р // Урядовий кур'єр від 11.05.2018 - № 88.

9. ЄС запускає в Україні нову програму EU4Digital для покращення онлайн-сервісів. 2019. URL: https://eeas. europa.eu/delegations/ukraine/62915 D0\%B2_uk.

10. Уряд хоче запровадити для держслужбовців віртуальні робочі місця. 2019. Zaxid.media. URL: http:// zaxid.media/news/5206757.

11 Лопушинський І.П. «Цифррові робочі місця» державних службовців як вагома складова електронного урядування в Україні. 2018. URL: http://el-zbirn-du.at.ua/2018_1/29.pdf.

12. Деякі питання організації електронної взаємодії державних електронних інформаційних ресурсів: Постанова Кабінету Міністрів України від 10 травня 2018 р. № 357. Урядовий кур'єр від 30.05.2018 - № 100.

13. Положення про електронну взаємодію державних електронних інформаційних ресурсів: затверджено Постановою Кабінету Міністрів України від 8 вересня 2016 року №606. Урядовий кур’єр від 14.09.2016 — № 172.

14. Порядок організації електронної інформаційної взаємодії державних електронних інформаційних ресурсів: затверджено Постановою Кабінету Міністрів України від 10 травня 2018 р. № 357. Урядовий кур’єр від 30.05.2018 - № 100 .

15. Положення про Національний реєстр електронних інформаційних ресурсів : Постанова Кабінету Міністрів України від 17 березня 2004 р. N 326. Офріційний вісник України від 02.04.2004. 2004 р. № 11, стор. 45, стаття 665, код акта 28119/2004.

\section{REFERENCES:}

1. Tsyfrova adzhenda Ukrainy - 2020 («Tsyfrovyi poriadok dennyi» - 2020): Kontseptualni zasady (versiia 1.0). Pershocherhovi sfery, initsiatyvy, proekty «tsyfrovizatsii» Ukrainy do 2020 roku: Proekt. [Digital Agenda of Ukraine - 2020 («Digital Agenda» - 2020): Conceptual principles (version 1.0) ]. URL: https:/lucci.org.ua/uploads/ files/58e78ee3c3922.pdf. [in Ukrainian]

2. Stratehiia reformuvannia derzhavnoho upravlinnia Ukrainy na 2016-2020 roky : Rozporiadzhennia Kabinetu Ministriv Ukrainy vid 24 chervnia 2016 r. № 474-r. [Public Administration Reform Strategy of Ukraine for 2016-2020: Order of the Cabinet of Ministers of Ukraine of June 24, 2016] Uriadovyi kurier ot 27.07.2016 — № 139 - Government courier from 07/27/2016 - № 139 [in Ukrainian]

3. Pro skhvalennia Kontseptsii rozvytku tsyfrovoi ekonomiky ta suspilstva Ukrainy na 2018-2020 roky ta zatverdzhennia planu zakhodiv shchodo yii realizatsii: Rozporiadzhennia Kabinetu Ministriv Ukrainy vid 17 sichnia 2018 r. № 67-r. [On approval of the Concept of development of the digital economy and society of Ukraine for 20182020 and approval of the action plan for its implementation: Order of the Cabinet of Ministers of Ukraine of January 17, 2018 № 67-r.]. Uriadovyi kurier vid 11.05.2018. № 88. Government courier from 11/05/2018. № 88 [in Ukrainian]

4. Poriadok dennyi asotsiatsii Ukraina - YeS dlia pidhotovky ta spryiannia implementatsii Uhody pro asotsiatsiiu. [EU-Ukraine Association Agenda for preparing and facilitating the implementation of the Association Agreement.].»Ukraina - Yevropeiskyi Soiuz: zibrannia mizhnarodnykh dohovoriv ta inshykh dokumentiv (19912009). 2009. - «Ukraine - European Union: Collection of International Treaties and Other Documents (1991-2009). URL: https://zakon.rada.gov.ua/laws/show/994_990/print [in Ukrainian]

5. Chernikov, D. (2019) Nyni v Yevropi uspishno realizuietsia stratehiia Yedynoho tsyfrovoho rynku [Chernikov D. Currently, the strategy of the Digital Single Market is being successfully implemented in Europe]. URL: https:// www.ukrinform.ua/rubric-economy/2364078-misia-ocifruvati-ekonomiku-strategia-edinogo-cifrovogo-rinku.html [in Ukrainian]

6. Pro skhvalennia Kontseptsii rozvytku elektronnoho uriaduvannia v Ukraini: Rozporiadzhennia Kabineta Ministriv Ukrainy vid 20.09.2017 № 649-r [On approval of the Concept of e-government development in Ukraine: Order of the Cabinet of Ministers of Ukraine dated 20.09.2017 № 649-r]: Uriadovyi kurier vid 27.09.2017 — № 181. — Government courier from 09/27/2017 - № 181 [in Ukrainian]

7. Pro skhvalennia Kontseptsii rozvytku elektronnoi demokratii v Ukraini ta planu zakhodiv shchodo yii realizatsii: Rozporiadzhennia Kabineta Ministriv Ukrainy vid 8 lystopada 2017 r. № 797-r. [On approval of the Concept for the development of e-democracy in Ukraine and the action plan for its implementation: Order of the Cabinet of Ministers 
of Ukraine of November 8, 2017 № 797-r]. Uriadovyi kurier vid 17.11.2017 — № 217. — Government courier from 11/17/2017 - № 217 [in Ukrainian].

8. Pro skhvalennia Kontseptsii rozvytku tsyfrovoi ekonomiky ta suspilstva Ukrainy na 2018-2020 roky ta zatverdzhennia planu zakhodiv shchodo yii realizatsii: Rozporiadzhennia Kabinetu Ministriv Ukrainy vid 17 sichnia 2018 r. № 67-r. [On approval of the Concept of development of the digital economy and society of Ukraine for 20182020 and approval of the action plan for its implementation: Order of the Cabinet of Ministers of Ukraine of January 17, 2018]. Uriadovyi kurier vid 11.05.2018 - № 88. - Government courier from 11.05.2018 - № 88 [in Ukrainian].

9. The EU is launching a new EU4Digital program in Ukraine to improve online services. 2019. [The EU is launching a new EU4Digital program in Ukraine to improve online services. 2019.] URL: https://eeas.europa.eu/delegations/ ukraine/62915 D0\%B2_uk [in Ukrainian].

10. Uriad khoche zaprovadyty dlia derzhsluzhbovtsiv virtualni robochi mistsia. [The government wants to create virtual jobs for civil servants.] 2019. Zaxid.media. URL: http://zaxid.media/news/5206757 [in Ukrainian].

11. Lopushynskyi I.P. (2018) «Tsyfrovi robochi mistsia» derzhavnykh sluzhbovtsiv yak vahoma skladova elektronnoho uriaduvannia v Ukraini. [Lopushinsky IP «Digital jobs» of civil servants as an important component of e-government in Ukraine.] 2018. URL: http://el-zbirn-du.at.ua/2018_1/29.pdf [in Ukrainian].

12. Deiaki pytannia orhanizatsii elektronnoi vzaiemodii derzhavnykh elektronnykh informatsiinykh resursiv: Postanova Kabinetu Ministriv Ukrainy vid 10 travnia $2018 \mathrm{r}$. [Some issues of organization of electronic interaction of state electronic information resources: Resolution of the Cabinet of Ministers of Ukraine of May 10, 2018 № 357.$]$ Uriadovyi kurier vid 30.05.2018 - № 100 - Government courier from 30.05.2018 [in Ukrainian].

13. Polozhennia pro elektronnu vzaiemodiiu derzhavnykh elektronnykh informatsiinykh resursiv: zatverdzheno Postanovoiu Kabinetu Ministriv Ukrainy vid 8 veresnia 2016 roku №606. [Regulations on electronic interaction of state electronic information resources: approved by the Resolution of the Cabinet of Ministers of Ukraine of September 8 , 2016 №606]. Uriadovyi kurier від 14.09.2016 - № 172. — Government courier 14.09.2016 — № 172 [in Ukrainian]

14. Poriadok orhanizatsii elektronnoi informatsiinoi vzaiemodii derzhavnykh elektronnykh informatsiinykh resursiv: zatverdzheno Postanovoiu Kabinetu Ministriv Ukrainy vid 10 travnia 2018 r. № 357 [Procedure for organizing electronic information interaction of state electronic information resources: approved by the Resolution of the Cabinet of Ministers of Ukraine of May 10, 2018 № 357]. Uriadovyi kurier vid 30.05.2018 — № 100. Government courier from 30.05.2018 - № 100 [in Ukrainian].

15. Polozhennia pro Natsionalnyi reiestr elektronnykh informatsiinykh resursiv : Postanova Kabinetu Ministriv Ukrainy vid 17 bereznia 2004 r. N 326 [Regulations on the National Register of Electronic Information Resources: Resolution of the Cabinet of Ministers of Ukraine of March 17, 2004 N 326]. Ofitsiinyi visnyk Ukrainy vid 02.04.2004. 2004 r. № 11, stor. 45, stattia 665, kod akta 28119/2004 — Official Gazette of Ukraine dated April 2, 2004. 2004. № 11 , p. 45 , Article 665 , code of act 28119/2004 [in Ukrainian]. 